\title{
Positive legacy effect of previous legume proportion in a ley on the performance of a following crop of Lolium multiflorum
}

\author{
Aaron Fox • Matthias Suter $(\mathbb{D} \cdot$ Franco Widmer • \\ Andreas Lüscher
}

Received: 5 September 2019 / Accepted: 13 December 2019/Published online: 20 December 2019

(C) The Author(s) 2019

\begin{abstract}
Aims We investigated the legacy effects of a previous ley's legume proportion on the performance of a following grass crop in a rotation.

Methods In April 2015, a pure Lolium multiflorum L. crop was sown after the removal of legume containing swards (0-100\% legumes), and was harvested four times over the following one-year period (3 times in 2015 and once the following April 2016). Labeled ${ }^{15} \mathrm{~N}$ fertilizer $\left(50 \mathrm{~kg} \mathrm{~N} \mathrm{ha}^{-1}\right)$ was applied during the $2 \mathrm{nd}$ and 3 rd re-growth periods to determine $\mathrm{N}$ fluxes.

Results Across the one-year period, a significant legume-legacy induced increase in biomass yield of L. multiflorum was observed over the entire range of previous legume proportions when compared against the non-legume ley, the effect being 2.15 and $1.73 \mathrm{t} \mathrm{ha}^{-1}(P \leq 0.001$ each $)$ in swards with $50 \%$ and $100 \%$ previous legume proportion, respectively, or up to $+31 \%$. The legume-legacy effect on biomass yield was most pronounced at the 1 st harvest (June) and persisted
\end{abstract}

Responsible Editor: Martin Weih.

Electronic supplementary material The online version of this article (https://doi.org/10.1007/s11104-019-04403-4) contains supplementary material, which is available to authorized users.

A. Fox $\cdot$ M. Suter $(\bowtie) \cdot$ A. Lüscher

Agroscope, Forage Production and Grassland Systems, Reckenholzstrasse 191, CH-8046 Zürich, Switzerland e-mail: matthias.suter@agroscope.admin.ch

A. Fox $\cdot$ F. Widmer

Agroscope, Molecular Ecology, Reckenholzstrasse 191, CH-8046 Zürich, Switzerland into the 2nd harvest in August $(P \leq 0.05$ both, over the entire range of previous legume proportion), though was no longer evident at the 3rd harvest (September). Importantly, the legume-legacy effect returned in the 4th harvest in April $(P \leq 0.05)$. Examining the source of $\mathrm{N}$ contributing to $\mathrm{N}$ yield confirmed that more $\mathrm{N}$ was derived from the soil at harvest 1 and 2 for previous legume containing leys $(P \leq 0.001)$ compared to those which contained no legumes, with a significant increase still seen for legume mixtures at harvest $3(P \leq 0.01)$. Conclusions The results demonstrate a sustained soiltransferred performance-enhancing legacy effect on a following crop in a rotation, with previous legume proportions of $50 \%$ having a comparable effect compared with that of a previous legume monoculture.

Keywords Legume-legacy effect $\cdot$ Biomass yield $\cdot \mathrm{N}$ content $\cdot \mathrm{N}$ yield $\cdot$ Following crop $\cdot{ }^{15} \mathrm{~N}$ fertilizer

\section{Introduction}

Modern intensively managed grassland-based production systems typically depend on high-performing pure grass swards, which require large inputs of nutrient fertilizers. Such systems give rise to considerable environmental concerns in relation to ground water pollution (Ledgard et al. 2009), greenhouse gas emissions (Shcherbak et al. 2014) as well as their overall sustainability. In light of these concerns, the adoption of grasslegume mixtures is seen as a viable alternative (Lüscher et al. 2014). Indeed, numerous benefits of such mixtures 
over conventional grass monocultures have been thoroughly demonstrated, such as increased biomass yield, nitrogen $(\mathrm{N})$ yield advantage and weed suppression (Connolly et al. 2018; Finn et al. 2013; Suter et al. 2015). Underpinning these advantages is the capacity for symbiotic fixation of atmospheric $\mathrm{N}_{2}$ by the legume component. The rate of symbiotic $\mathrm{N}_{2}$ fixation can range from 100 to $380 \mathrm{~kg} \mathrm{~N} \mathrm{ha}^{-1}$ year $^{-1}$ in pastures in the northern temperate/boreal regions and is dependent on numerous factors, including legume species and legume proportion, prevailing environmental conditions and grassland management practices (Hansen and Vinther 2001; Ledgard and Steele 1992; Nyfeler et al. 2011). Over time, this process alters both the quantity and chemical composition of underlying soil organic matter, as legume residues are known to have a high $\mathrm{N}$ content and a low C/N ratio (Sieling 2019; Sievers and Cook 2018). Such legume-induced alterations can strongly benefit non-legumes in a mixed sward as there is significant potential for belowground $\mathrm{N}$ transfer (HøghJensen and Schjoerring 1997; Oberson et al. 2013), which can occur, amongst other ways, via legume root and root exudate decomposition (Fustec et al. 2010; Hammelehle et al. 2018). For example in legumes, $\mathrm{N}$ rhizodeposition can make up to $70 \%$ of their total plant $\mathrm{N}$ (Fustec et al. 2010). These mechanisms of $\mathrm{N}$ transfer of soil legume deposits to other plants would suggest that legume species have a strong potential to impart lasting effects that influence the agronomic potential of agricultural systems. The lower C:N ratio of these deposits is assumed to induce their mineralization, increasing the soil $\mathrm{N}$ availability of the following crop (Karlen et al. 1994; reviewed in Sieling 2019). Indeed in crop rotation systems, soil mineral $\mathrm{N}$ measured the following year after annual grain legumes was significantly greater than after non-legume controls (Peoples et al. 2017). In agreement, subsequent beneficial effects on cereal crop performance following the legume monoculture (such as the pea plant Pisum sativum) have been demonstrated (e.g. Evans et al. 1991; Stevenson and van Kessel 1996). Such beneficial legacy effects on a following crop have not generally been studied for systems where the preceding crop was a ley for several years (but see Rasmussen et al. 2012). In such a system, a legumeinduced legacy effect on a following crop would need to exceed the effect of a pure grass ley, which is already a beneficial system regarding soil quality due to the absence of tillage and a positive effect on soil organic matter (as compared to annual crops) (Crème et al.
2018; Soussana and Lemaire 2014). Nevertheless, legume-induced legacy effects of temporary grasslands have been hinted at in the Agrodiversity Experiment, a legume-containing mixtures experiment conducted on a broad European pedo-climatic gradient. In this experiment, a clear decline in legume abundance in mixtures over its three-year duration was observed. Despite this, a significant positive legume-effect on yield was sustained in the 3 rd year in 18 out of the 24 sites tested, even as the legume proportion declined to very low levels (Brophy et al. 2017). The objective of our study was to verify and find the explanatory mechanism behind this observation. We targeted the performance of a following crop of Lolium multiflorum L., a ryegrass which is highly competitive for $\mathrm{N}$, after legumecontaining swards from a previous mixtures experiment were completely removed. The principle aim was deducing whether any legume-induced legacy effects were transmitted through the soil. Specifically, the following questions were addressed:

1) Are there any positive legacy effects of a previous ley's legume presence and abundance on the biomass yield, $\mathrm{N}$ content and $\mathrm{N}$ yield of a following grass monoculture?

2) Are these legacy effects transferred through increased $\mathrm{N}$ derived from the soil?

3) How long are such effects sustained?

4) What proportion of legumes are required in a previous mixture to obtain maximum benefits?

\section{Materials and methods}

Experimental set-up and maintenance

A field mixtures experiment was conducted at ZürichReckenholz $\left(47^{\circ} 26^{\prime} \mathrm{N}, 8^{\circ} 32^{\prime} \mathrm{E}, 491 \mathrm{~m}\right.$ a.s.l, mean annual temperature: $9.4^{\circ} \mathrm{C}$, mean annual precipitation: $1031 \mathrm{~mm}$ ), on a cambisol (top soil 42\% silt, 26\% clay, $\mathrm{pH}=7.1$ ) over a period of 3 years (2012-2014, a typical length for a grassland in a crop-rotation). The experiment utilized four model plant species: two non-legume species, the grass Lolium perenne L. (cultivar (cv.) Alligator) and the forb Cichorium intybus L. (cv. Puna II), and the two legume species Trifolium repens L. (cv. Hebe) and Trifolium pratense L. (cv. Dafila). The legume proportion of the seed mix was 14,50 or $86 \%$ and 
0 or $100 \%$ in monocultures, grown on a plot size of $3 \times$ $5 \mathrm{~m}$ (see Appendix 1, supplementary material, for information on the type of the previous communities sown, and consult Hofer et al. 2016, 2017 for full details). Upon the completion of this experiment, the legume proportion of the plots was again measured, and was well distributed over the whole range from 0 to 100\% (Fig. 1a). In the spring of 2015 (April 21st), these preceding swards were removed using a commercial formulation of a glyphosate herbicide (Roundup ${ }^{\circledR}$, Monsanto, MI, USA) and all plots were re-seeded via rotary harrow with a pure Lolium multiflorum L. crop (a total of 113 plots were used for this experiment). This following sward was allowed to become established and was subsequently harvested three times during 2015 (June 26th, August 10th and September 24th) and once in 2016 (April 27th). In each plot, aboveground biomass was harvested in a central stripe of $5 \times 1.5 \mathrm{~m}$ to a height of $7 \mathrm{~cm}$ using an experimental plot harvester (Hege 212, Wintersteiger) and the total dry matter yield was determined. $\mathrm{A}^{15} \mathrm{~N}$ labeled fertilizer (in the form of doublelabeled $\mathrm{NH}_{4} \mathrm{NO}_{3}$ ) was applied during the 2nd and 3rd re-growth periods in 2015 (50 $\mathrm{kg} \mathrm{N} \mathrm{ha}^{-1}$ each). This was done to differentiate $\mathrm{N}$ sources (fertilizer or soil) in the following plant biomass. If a legume-legacy effect was soil-transferred, a greater amount of $\mathrm{N}$ would be derived from that source in previous legume-containing plots due to a higher organo- $\mathrm{N}$ content. The ${ }^{15} \mathrm{~N}$ atom percent excess $\left({ }^{15} \mathrm{NH}_{4}{ }^{15} \mathrm{NO}_{3}\right)$ of fertilizer was $0.57 \%$, a label used successfully in comparable studies (e.g. Nyfeler et al. 2011) and corresponding to a $\delta^{15} \mathrm{~N}$ of $1557 \%$, being about three order of magnitude above the limit of detection of significant differences in plant samples (Oberson et al. 2013; Unkovich et al. 1994). The spring re-growth period in 2016 also received fertilization, but with a non-labeled commercial $\mathrm{N}$ fertilizer $\left(50 \mathrm{~kg} \mathrm{~N} \mathrm{ha}{ }^{-1}\right)$. Nitrogen content was measured from a representative subsample of the harvested material using a LECO Truespec CN analyzer. The determination of ${ }^{15} \mathrm{~N}$ content from the material of the applicable harvests was done using an elemental analyzer interfaced to a continuous flow isotope ratio mass spectrometer (Stable Isotope Facility, UC Davis, USA).

Percent $\mathrm{N}$ derived from fertilizer (Ndff) in the aboveground biomass of L. multiflorum was calculated following Vose and Victoria (1986):

$\operatorname{Ndff}(\%)=\frac{B-A}{C-A} * 100$ where $\mathrm{A}$ is the ${ }^{15} \mathrm{~N}$ natural abundance $(0.366 \%)$, $\mathrm{B}$ is the ${ }^{15} \mathrm{~N}$ atom percent in the plant biomass and $\mathrm{C}$ is the ${ }^{15} \mathrm{~N}$ atom percent in the applied fertilizer. Because ${ }^{15} \mathrm{~N}$ was applied twice (2nd and 3rd regrowth 2015), Ndff in the 3 rd harvest represents the percentage of $\mathrm{N}$ derived from both fertilizer applications. Percent $\mathrm{N}$ derived from soil in aboveground biomass of L. multiflorum was the \% difference of that calculated from the above equation $(100 \%-N d f f)$. The amount of $\mathrm{N}\left(\mathrm{kg} \mathrm{N} \mathrm{ha}^{-1}\right)$ harvested from the two fractions was calculated using the total $\mathrm{N}$ content in L. multiflorum and its respective dry mass.

Data analysis

For analysis purposes, biomass of the two legume species in previous leys was pooled as the proportion of white clover had strongly declined during the course of the previous mixtures experiment. Additionally, a preliminary analysis revealed that the response of biomass and $\mathrm{N}$ yield of L. multiflorum in previous leys with the two non-legume species was very similar, and so biomass of the two non-legume species was also pooled. Nitrogen yield was calculated as biomass yield times $\mathrm{N}$ content, while the Nitrogen Nutrition Index (NNI, the ratio of $\mathrm{N}$ content in biomass to the $\mathrm{N}$ content needed for $\mathrm{N}$-unlimited growth) of the following L. multiflorum crop biomass was calculated following Lemaire and Gastal (1997). Legume-legacy effects on biomass yield of L. multiflorum, its $\mathrm{N}$ content, $\mathrm{N}$ yield, the NNI as well as $\mathrm{N}$ yield derived from soil and fertilizer were estimated via linear regression or linear mixed-effects regression. Linear models were used for estimations of the total sum of all 4 harvests, with the explanatory variable being the previous realized legume proportion (2014), including a quadratic legume proportion term to allow for flexibility in the response curves. Linear mixed-effects models were used for estimations of the four repeated harvests over the experimental duration (Pinheiro and Bates 2000). These models included the fixed explanatory variables 'previous realized legume proportion', a quadratic legume proportion term, harvest number (factor of four levels for each of the four harvests), and all interactions. In addition, a random plot variable (random intercept) and an unstructured co-variance matrix among residuals was included to account for potential correlation over harvests. The marginal and conditional $R^{2}$ of mixed-effects models were computed following Nakagawa and Schielzeth (2013), and a summary of these analyses is provided in Tables S.1 and S.2, 

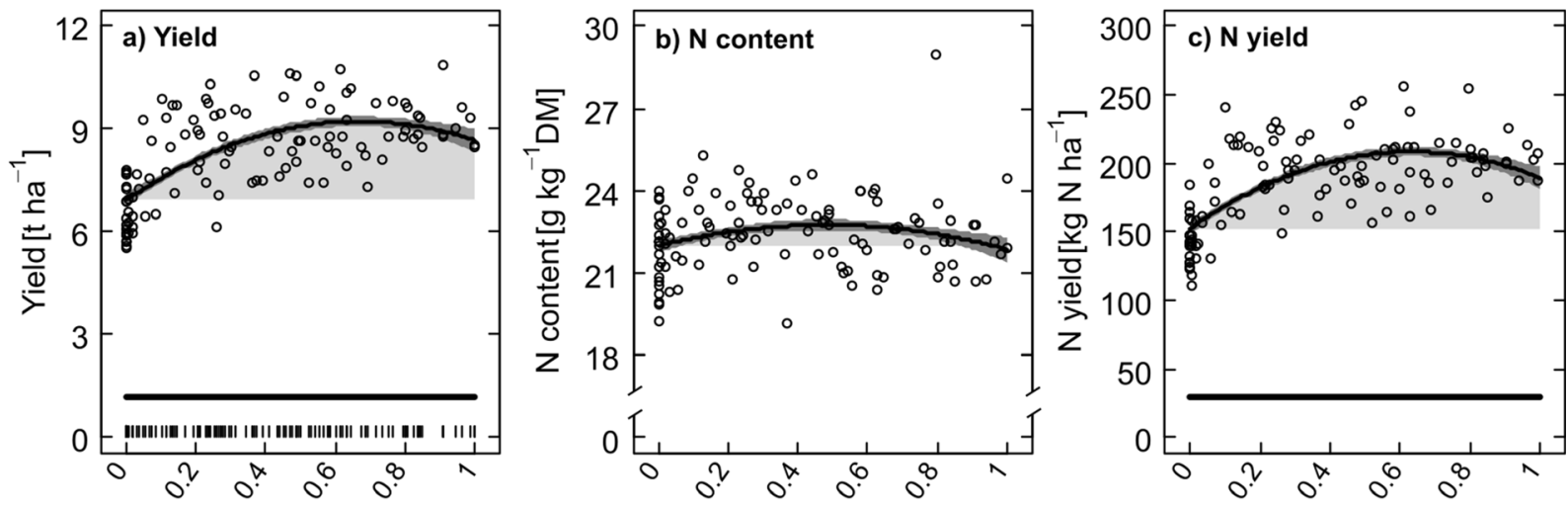

\section{Legume proportion of previous ley}

Fig. 1 Total biomass yield (a), $\mathrm{N}$ content (b), and $\mathrm{N}$ yield (c) obtained in a following crop of $L$. multiflorum in the 4 combined harvests as a function of the previous ley's legume proportion. Displays are the measured data and predicted lines ( \pm SE, dark grey shaded) based on linear regression models. Light shaded area under predicted lines represents legume-legacy increases over

supplementary material. Estimates and standard errors of the difference in response variables between previous legume containing leys and non-legume monocultures (i.e., the legume-legacy effect) were calculated as the difference in the value of regression coefficients and their variances (see Appendix 1, supplementary material, for details). The range of legume proportions for which any of the response variables were significantly different from the non-legume monoculture was calculated using the Johnson-Neyman technique (Johnson and Neyman 1936; Potthoff 2006). All data was analyzed with the statistics software R, version 3.6.0 (R Development Core Team 2019).

\section{Results}

Strong legacy effect of previous ley's legume proportion on following crop's yield

When considering the L. multiflorum biomass yield for the total one-year experimental period (i.e., harvest 1-4 combined), a clear and significant increase, i.e. a legumelegacy effect, was obtained over the entire range of previous legume proportions (Fig. 1a). In previous mixtures with only $50 \%$ legume proportion (hereafter ' $\mathrm{Leg}_{50}$ '), this resulted in $2.15 \mathrm{t} \mathrm{ha}^{-1}$ or $+31 \%$ more biomass yield of L. multiflorum than in previous non-legume monocultures (hereafter 'Non-Leg') $(P \leq 0.001$, Table 1). In comparison, the legacy effect on biomass yield in previous previous non-legume ley, and the horizontal bold line at the bottom covers the range of legume proportion for which legume-legacy increases were significant $(P \leq 0.05$, no line indicates non-significance). Notches at the bottom of panel a) indicate the legume proportion of the previous ley from individual plots

legume monocultures (hereafter ' $\mathrm{Leg}_{\text {mono }}$ ') was $1.73 \mathrm{t} \mathrm{ha}^{-1}$ or $+25 \%(P \leq 0.001$, Fig. 1a, Table 1). Notably, the difference in biomass yield between $\operatorname{Leg}_{50}$ and Leg $_{\text {mono }}$ was not significant (Table 1), indicating a saturation of the legacy effect with increasing legume proportion of the previous ley. Looking at the individual harvests, there was a significant legume-legacy effect on L. multiflorum biomass yield over the entire range of legume proportions at the 1st harvest after the removal of the swards (Fig. 2a). In $\operatorname{Leg}_{50}$, this was $1.20 \mathrm{tha}^{-1}$ or + $132 \%$, while in $\mathrm{Leg}_{\text {mono }}$, it was $1.05 \mathrm{t} \mathrm{ha}^{-1}$ or $+115 \%$ $(P \leq 0.001$ each, Table 1). Equitable increases over the biomass yield from Non-Leg were also obtained at the 2nd harvest in previous legume containing leys, the effect being $\sim+40 \%$ in $\operatorname{Leg}_{50}$ and $\operatorname{Leg}_{\text {mono }}(P \leq 0.05$, Fig. $2 b)$. The legume-legacy effect on biomass yield was not detected at the 3rd harvest (Fig. 2c); however, it returned at the 4th harvest in spring 2016 (Fig. 2d), where an increase in L. multiflorum biomass yield was achieved in almost all previous legume mixtures over Non-Leg (e.g. $+0.43 \mathrm{tha}^{-1}$ or $+15 \%$ in $\operatorname{Leg}_{50}, P \leq 0.001$ ). Importantly, no significant difference in biomass yields was observed between $\operatorname{Leg}_{50}$ and Leg $_{\text {mono }}$ in any of the individual harvests.

Legume-legacy effect on the $\mathrm{N}$ content and $\mathrm{N}$ yield of the following L. multiflorum crop

In the experimental period as a whole, there was no effect of previous legume-containing swards on the biomass $\mathrm{N}$ content of the following L. multiflorum crop $(P>0.05$, 
Table 1 Effect of three stand types of the previous ley and the legume legacy effect on the biomass yield of a following crop of pure L. multiflorum in the first year following sowing (Harvest 14) and in each of the constituent individual harvests. Non-Leg: Non-Legume monoculture, $\operatorname{Leg}_{50}$ : Legume mixture with $50 \%$ legume proportion, Leg $_{\text {mono: }}$ Legume monoculture. Given are predicted means ( $\pm 1 \mathrm{SE}$ ) from regression models. The $R^{2}$ of the combined model (Harvest 1-4) was 0.43 , while the marginal and conditional $R^{2}$ of the repeated-measure model were 0.80 and 0.88 , respectively

\begin{tabular}{|c|c|c|c|c|c|}
\hline & & $\begin{array}{l}\text { Non-Leg } \\
(0 \%)^{\mathrm{a}}\end{array}$ & $\begin{array}{l}\operatorname{Leg}_{50} \\
(50 \%)\end{array}$ & & $\begin{array}{l}\text { Leg }_{\text {mono }} \\
(100 \%)\end{array}$ \\
\hline \multicolumn{2}{|c|}{ Yield L. multiflorum } & $\left(\mathrm{t} D M h^{-1}\right)$ & $\left(\mathrm{t} \mathrm{DM} \mathrm{ha}{ }^{-1}\right)$ & & $\left(\mathrm{t} \mathrm{DM} \mathrm{ha}{ }^{-1}\right)$ \\
\hline & Harvest $1-4$ & $6.93( \pm 0.177)$ & $9.08( \pm 0.152)$ & $\mathrm{ns}^{\mathrm{b}}$ & $8.66( \pm 0.337)$ \\
\hline \multirow[t]{3}{*}{2015} & Harvest 1 & $0.91( \pm 0.066)$ & $2.11( \pm 0.056)$ & ns & $1.96( \pm 0.125)$ \\
\hline & Harvest 2 & $1.01( \pm 0.066)$ & $1.41( \pm 0.056)$ & ns & $1.43( \pm 0.125)$ \\
\hline & Harvest 3 & $2.09( \pm 0.066)$ & $2.21( \pm 0.056)$ & ns & $2.10( \pm 0.125)$ \\
\hline 2016 & Harvest 4 & $2.92( \pm 0.066)$ & $3.35( \pm 0.056)$ & ns & $3.17( \pm 0.125)$ \\
\hline \multicolumn{2}{|c|}{ Legume legacy effect ${ }^{\mathrm{c}}$} & & $\left(\mathrm{t} \mathrm{DM} \mathrm{ha}{ }^{-1}\right)$ & & $\left(\mathrm{t} \mathrm{DM} \mathrm{ha}{ }^{-1}\right)$ \\
\hline & Harvest $1-4$ & - & $2.15( \pm 0.257)^{* * *}$ & & $1.73( \pm 0.347)^{* * *}$ \\
\hline \multirow[t]{3}{*}{2015} & Harvest 1 & - & $1.20( \pm 0.096) * * *$ & & $1.05( \pm 0.129) * * *$ \\
\hline & Harvest 2 & - & $0.40( \pm 0.096)^{* *}$ & & $0.42( \pm 0.129)^{*}$ \\
\hline & Harvest 3 & - & $0.12( \pm 0.096)^{\mathrm{ns}}$ & & $0.01( \pm 0.129)^{\mathrm{ns}}$ \\
\hline 2016 & Harvest 4 & - & $0.43( \pm 0.096)^{* * *}$ & & $0.25( \pm 0.129)^{\mathrm{ns}}$ \\
\hline
\end{tabular}

${ }^{a}$ Percentage of the previous ley's legume proportion

${ }^{\mathrm{b}} t$-test of difference in biomass yield between $\operatorname{Leg}_{50}$ and $\operatorname{Leg}_{\mathrm{mono}}$

${ }^{\mathrm{c}}$ Increase in biomass yield of $L$. multiflorum grown at $\mathrm{Leg}_{50}$ and $\mathrm{Leg}_{\mathrm{mon}}$ as compared to L. multiflorum grown at Non-Leg $* * * P \leq 0.001, * * P \leq 0.01, * P \leq 0.05, \mathrm{~ns} P>0.05$

Fig. 1b). Nevertheless, at the 1st harvest, there was a significant increase in the biomass $\mathrm{N}$ content for almost the entire range of previous mixture legume proportions (up to $94 \%$ legumes), the effect being up to $2.3 \mathrm{~g} \mathrm{~N} \mathrm{~kg}^{-1}$ $\mathrm{DM}$ in $\operatorname{Leg}_{50}$ (Fig. 2e, $P \leq 0.001$, Table 2). As a result, $\mathrm{N}$ yield of $L$. multiflorum revealed similar patterns as its biomass yield. For the one-year period, a highly significant legume-legacy effect was observed on $\mathrm{N}$ yield over the entire range of previous mixture legume proportions (Fig. 1c), with an increase of $53.4 \mathrm{~kg} \mathrm{~N} \mathrm{ha}{ }^{-1}$ or $+35 \%$ in $\operatorname{Leg}_{50}$ compared to Non-Leg, and $36.9 \mathrm{~kg} \mathrm{~N}^{-1}$ or $+24 \%$ in $\operatorname{Leg}_{\text {mono }}$ $(P \leq 0.001$ each, Table 3$)$. No significant difference in $\mathrm{N}$ yield was observed between $\operatorname{Leg}_{50}$ and Leg $_{\text {mono }}$ (Table 3 ). $>$ At individual harvests, legume-legacy effects on $\mathrm{N}$ yield were largest at the 1st harvest (Fig. 2i), where they amounted up to $29.3 \mathrm{~kg} \mathrm{~N} \mathrm{ha}{ }^{-1}$ or $+153 \%$ in $\operatorname{Leg}_{50}(P \leq$ 0.001 , Table 3$)$. Legume-legacy effects were not detected at the 3rd harvest (Fig. 21), but returned at the 4th harvest the following spring (Fig. 2m). There, a significant increase in $\mathrm{N}$ yield of $L$. multiflorum was achieved over Non-Leg for a large range of the previous mixture legume proportions $\left(8.8 \mathrm{~kg} \mathrm{~N} \mathrm{ha}^{-1}\right.$ or $+15 \%$ in $\operatorname{Leg}_{50}, P \leq 0.01$, Table 3$)$.
The NNI in biomass of $L$. multiflorum was significantly enhanced in previous legume containing leys at the $1 \mathrm{st}$ (over the whole range of legume proportion) and 2nd harvest (up to $97 \%$ legume proportion), though not at later harvests (Fig. S.1). For example at the 1st harvest, the NNI increased from 0.45 in Non-Leg to 0.61 and 0.58 in $\mathrm{Leg}_{50}$ and $\operatorname{Leg}_{\text {mono, }}$ respectively $(P \leq 0.001$ each, Table S.3 in supplementary material). Notably, the NNI of L. multiflorum was $<1$ at all previous stand types at all 4 harvests, indicating that $L$. multiflorum grew under $\mathrm{N}$ limiting conditions for the duration of the experiment.

\section{Contributing sources to $\mathrm{N}$ yield}

As there was no fertilizer application at the first harvest, the impressive increase in $\mathrm{N}$ yield in both $\operatorname{Leg}_{50}$ $\left(29.3 \mathrm{~kg} \mathrm{~N} \mathrm{ha}^{-1}\right)$ and $\operatorname{Leg}_{\text {mono }}\left(25.5 \mathrm{~kg} \mathrm{Nha}^{-1}\right)$ was entirely soil-derived N $(P \leq 0.001$ each, Table 3$)$. At the 2 nd harvest, there was a significant legume-legacy induced increase in soil-derived $\mathrm{N}$ uptake over the entire range of previous legume proportions compared to Non-Leg (Fig. $2 \mathrm{k}$, approx. $7 \mathrm{~kg} \mathrm{~N} \mathrm{ha}^{-1}$ in $\mathrm{Leg}_{50}$ and $\mathrm{Leg}_{\text {mono }}$, respectively $(P \leq 0.001)$, or $+52 \%$ and $+53 \%$, Table S.4). There was 


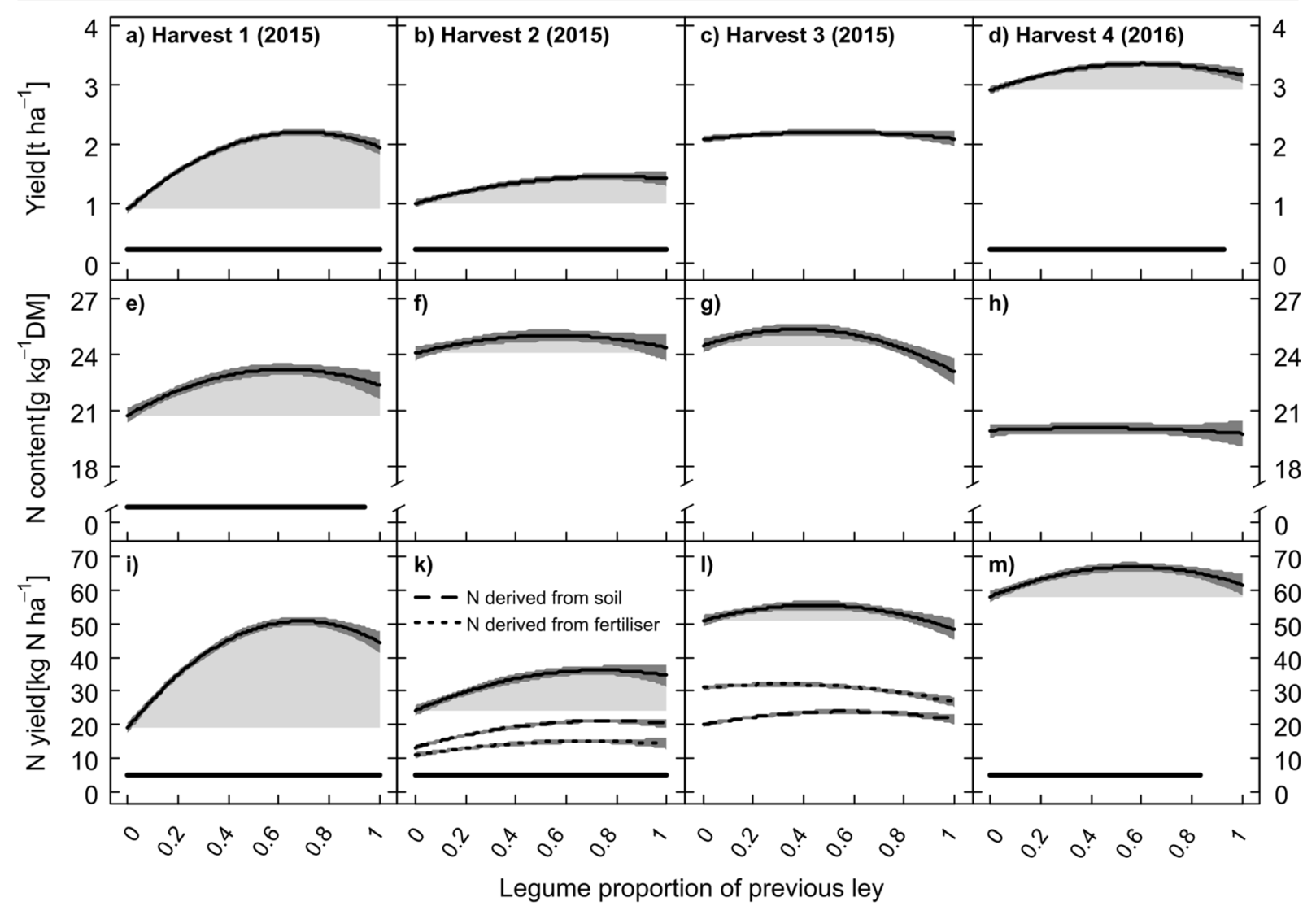

Fig. 2 Biomass yield (panels a to d), N content (panels e to $\mathbf{h}$ ), and $\mathrm{N}$ yield (panels $\mathbf{i}$ to $\mathbf{m}$ ) obtained in a following crop of L. multiflorum in each of the 4 experimental harvests as a function of the previous ley's legume proportion. Displays are predicted lines ( \pm SE, dark grey shaded) based on linear mixed-effects regression models. Light shaded area under predicted lines represents legume-legacy increases over previous non-legume ley. The horizontal bold line at the bottom covers the range of legume proportion for which legume-legacy increases were significant $(P \leq 0.05$, no line indicates non-significance). $\mathrm{N}$ yield derived from soil and fertilizer at the 2nd and 3rd harvests (panels $\mathbf{k}$ and I) is also displayed. Note that in panel $\mathbf{i}$, all $\mathrm{N}$ yield is derived from soil as no fertilizer was applied to harvest 1 also an increase in fertilizer-derived $\mathrm{N}$ uptake, the effect being $3.8 \mathrm{~kg}(P \leq 0.05)$ and $3.4 \mathrm{~kg} \mathrm{~N}^{-1}(P>0.05)$ in $\operatorname{Leg}_{50}$ and $\mathrm{Leg}_{\text {mono }}$, respectively, or $+35 \%$ and $+31 \%$ (Table S.5). Soil N generally contributed a greater portion to total $\mathrm{N}$ yield than did fertilizer $\mathrm{N}$ at this 2 nd harvest (Fig. $2 \mathrm{k})$. At the $3 \mathrm{rd}$ harvest, a significant increase in soil-derived $\mathrm{N}$ was still seen in $\operatorname{Leg}_{50}$ (approx. $4 \mathrm{~kg} \mathrm{~N} \mathrm{ha}{ }^{-1}$ or $+20 \%$, $P \leq 0.01$ ), though this was no longer the case in $\mathrm{Leg}_{\text {mono }}$ (Fig. 21, Table S.4). No legacy-associated increases were seen in fertilizer-derived $\mathrm{N}$ at the 3rd harvest (Table S.5).

\section{Discussion}

We observed an impressive, legume-legacy induced growth promotion in a following L. multiflorum crop and an increase in its $\mathrm{N}$ yield (each up to $+130 \%$ ) over a wide range of previous mixture legume proportions at the 1st harvest after the removal of the previous swards, with the legume-legacy effect even lasting into a further growing season. The experimental design employed indicates that this effect is entirely soil-transferred (old sward removed, new crop established). Such a soiltransferred effect could have been transmitted in a number of ways, such as $\mathrm{N}$ being made available from decaying root exudates, or an increase in soil organic matter derived by symbiotic $\mathrm{N}_{2}$ fixation by the previous legume component of the ley (Fustec et al. 2010). Residues of white clover have been shown to have high initial mineralization rates after their incorporation into the soil matrix (de Neergaard et al. 2002), with the potential of increasing the available-N pool to a following crop. 
Table 2 Effect of three stand types of the previous ley and the legume legacy effect on $\mathrm{N}$ content of a following crop of pure L. multiflorum in the first year following sowing (Harvest 1-4) and in each of the constituent individual harvests. Non-Leg: NonLegume monoculture, $\operatorname{Leg}_{50}$ : Legume mixture with $50 \%$ legume

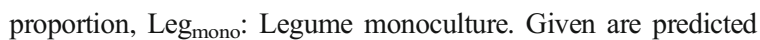
means ( $\pm 1 \mathrm{SE}$ ) from regression models. The $R^{2}$ of the combined model (Harvest $1-4$ ) was 0.05 , while the marginal and conditional $R^{2}$ of the repeated-measure model were 0.47 and 0.55 , respectively

\begin{tabular}{|c|c|c|c|c|c|}
\hline & & $\begin{array}{l}\text { Non-Leg } \\
(0 \%)^{\mathrm{a}}\end{array}$ & $\begin{array}{l}\operatorname{Leg}_{50} \\
(50 \%)\end{array}$ & & $\begin{array}{l}\text { Leg }_{\text {mono }} \\
(100 \%)\end{array}$ \\
\hline \multicolumn{2}{|c|}{$\mathrm{N}$ content $L$. multiflorum } & $\left(\mathrm{g} \mathrm{N} \mathrm{kg}^{-1} \mathrm{DM}\right)$ & $\left(\mathrm{g} \mathrm{N} \mathrm{kg}^{-1} \mathrm{DM}\right)$ & & $\left(\mathrm{g} \mathrm{N} \mathrm{kg}^{-1} \mathrm{DM}\right)$ \\
\hline & Harvest $1-4$ & $22.0( \pm 0.24)$ & $22.8( \pm 0.21)$ & $\mathrm{ns}^{\mathrm{b}}$ & $21.9( \pm 0.46)$ \\
\hline \multirow[t]{3}{*}{2015} & Harvest 1 & $20.8( \pm 0.38)$ & $23.1( \pm 0.32)$ & ns & $22.3( \pm 0.72)$ \\
\hline & Harvest 2 & $24.0( \pm 0.38)$ & $25.0( \pm 0.32)$ & $\mathrm{ns}$ & $24.4( \pm 0.72)$ \\
\hline & Harvest 3 & $24.5( \pm 0.38)$ & $25.3( \pm 0.32)$ & $*$ & $23.1( \pm 0.72)$ \\
\hline 2016 & Harvest 4 & $19.9( \pm 0.38)$ & $20.1( \pm 0.32)$ & $\mathrm{ns}$ & $19.8( \pm 0.72)$ \\
\hline \multicolumn{2}{|c|}{ Legume legacy effect ${ }^{\mathrm{c}}$} & & $\left(\mathrm{g} \mathrm{N} \mathrm{kg}^{-1} \mathrm{DM}\right)$ & & $\left(\mathrm{g} \mathrm{N} \mathrm{kg}^{-1} \mathrm{DM}\right)$ \\
\hline & Harvest $1-4$ & - & $0.8( \pm 0.35)^{\mathrm{ns}}$ & & $-0.1( \pm 0.47)^{\mathrm{ns}}$ \\
\hline \multirow[t]{3}{*}{2015} & Harvest 1 & - & $2.3( \pm 0.55)^{* * *}$ & & $1.5( \pm 0.74)^{\mathrm{ns}}$ \\
\hline & Harvest 2 & - & $1.0( \pm 0.55)^{\mathrm{ns}}$ & & $0.4( \pm 0.74)^{\mathrm{ns}}$ \\
\hline & Harvest 3 & - & $0.8( \pm 0.55)^{\mathrm{ns}}$ & & $-1.4( \pm 0.74)^{\mathrm{ns}}$ \\
\hline 2016 & Harvest 4 & - & $0.2( \pm 0.55)^{\mathrm{ns}}$ & & $-0.1( \pm 0.74)^{\mathrm{ns}}$ \\
\hline
\end{tabular}

a Percentage of the previous ley's legume proportion

${ }^{\mathrm{b}} t$-test of difference in $\mathrm{N}$ content between $\mathrm{Leg}_{50}$ and $\mathrm{Leg}_{\text {mono }}$

${ }^{\mathrm{c}}$ Change in $\mathrm{N}$ content of L. multiflorum grown at $\mathrm{Leg}_{50}$ and $\mathrm{Leg}_{\text {mono }}$ as compared to L. multiflorum grown at Non-Leg *** $P \leq 0.001, * P \leq 0.05$, ns $P>0.05$

While legacy-associated increases from annual legume crops to following cereal crop performance are well-documented (e.g., Anderson 2011; Evans et al. 1991; Peoples et al. 2009; Stevenson and van Kessel 1996), the results demonstrated here are highly relevant as they relate to a ley, not an annual crop within a crop rotation system, which has not been previously reported. Also, the magnitude of the legume-associated legacy effect was compared against a perennial non-legume ley, which in terms of the maintenance of soil quality is already a good system, due to no soil cultivation and the maintenance of soil organic matter (Crème et al. 2018; Franzluebbers et al. 2014; Soussana and Lemaire 2014). Therefore, the demonstration of strongly beneficial effects of grass-legume mixtures over what is already an agronomically beneficial system (the nonlegume ley) is important.

The specific manner in which the legume-induced legacy effect on L. multiflorum performance manifested itself over the course of this experiment (strong effect in the 1 st harvest, reduced in the $2 \mathrm{nd}$, undetectable in the third and then returning in the 4th harvest) may be due to the effect of seasonal progression on soil nutrient availability. In temperate climates, soil $\mathrm{N}$ availability in autumn is greater than that during summer months (Murphy et al. 2007); moreover, growth is reduced due to the lower temperature and radiation in autumn, both reducing $\mathrm{N}$ limitation in plants. Additionally, the dry summer conditions in Zurich in 2015 (precipitation reduced by $-33 \%$ in June, July, and August compared to 30-year average of 1981-2010, MeteoSwiss), followed by a re-wetting of the soil in autumn, may have resulted in a flush of $\mathrm{N}$ becoming available through mineralization (Borken and Matzner 2009; Hofer et al. 2017). A combination of these factors may have resulted in relatively more $\mathrm{N}$ becoming available at the $3 \mathrm{rd}$ harvest in the autumn, also seen in the increase in the NNI in previous non-legume monocultures (Fig. S.1c), and an attenuation of the legume-legacy benefit. The return of a positive legume-legacy effect in the following spring of 2016 indicates that it can sustain even past one growing season, though at a reduced magnitude. This fits with previous observations in arable systems (Anderson 2011).

The non-linear nature of the legacy effect (i.e., the previous $\operatorname{Leg}_{50}$ mixture having a comparable effect to 
Table 3 Effect of three stand types of the previous ley and the legume legacy effect on the $\mathrm{N}$ yield of a following crop of pure L. multiflorum in the first year following sowing (Harvest 1-4) and in each of the constituent individual harvests. Non-Leg: NonLegume monoculture, $\operatorname{Leg}_{50}$ : Legume mixture with $50 \%$ legume

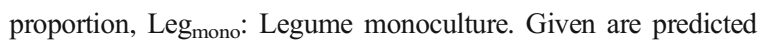
means ( $\pm 1 \mathrm{SE}$ ) from regression models. The $R^{2}$ of the combined model (Harvest $1-4$ ) was 0.44 , while the marginal and conditional $R^{2}$ of the repeated-measure model were 0.70 and 0.79 , respectively

\begin{tabular}{|c|c|c|c|c|c|}
\hline & & $\begin{array}{l}\text { Non-Leg } \\
(0 \%)^{\mathrm{a}}\end{array}$ & $\begin{array}{l}\operatorname{Leg}_{50} \\
(50 \%)\end{array}$ & & $\begin{array}{l}\text { Leg }_{\text {mono }} \\
(100 \%)\end{array}$ \\
\hline \multicolumn{2}{|c|}{$\mathrm{N}$ yield $L$. multiflorum } & $\left(\mathrm{kg} \mathrm{N} \mathrm{ha}^{-1}\right)$ & $\left(\mathrm{kg} \mathrm{N} \mathrm{ha}^{-1}\right)$ & & $\left(\mathrm{kg} \mathrm{N} \mathrm{ha}^{-1}\right)$ \\
\hline & Harvest $1-4$ & $152.5( \pm 4.22)$ & $205.9( \pm 3.62)$ & $\mathrm{ns}^{\mathrm{b}}$ & $189.4( \pm 8.03)$ \\
\hline \multirow[t]{3}{*}{2015} & Harvest 1 & $19.1( \pm 1.64)$ & $48.4( \pm 1.40)$ & $\mathrm{ns}$ & $44.6( \pm 3.12)$ \\
\hline & Harvest 2 & $24.1( \pm 1.64)$ & $35.0( \pm 1.40)$ & ns & $34.6( \pm 3.12)$ \\
\hline & Harvest 3 & $51.0( \pm 1.64)$ & $55.6( \pm 1.40)$ & $\mathrm{ns}$ & $48.4( \pm 3.12)$ \\
\hline 2016 & Harvest 4 & $58.2( \pm 1.64)$ & $67.0( \pm 1.40)$ & $\mathrm{ns}$ & $61.8( \pm 3.12)$ \\
\hline \multicolumn{3}{|c|}{ Legume legacy effect ${ }^{\mathrm{c}}$} & $\left(\mathrm{kg} \mathrm{N} \mathrm{ha}{ }^{-1}\right)$ & & $\left(\mathrm{kg} \mathrm{N} \mathrm{ha}^{-1}\right)$ \\
\hline & Harvest $1-4$ & - & $53.4( \pm 6.13)^{* * *}$ & & $36.9( \pm 8.28)^{* * *}$ \\
\hline \multirow[t]{3}{*}{2015} & Harvest 1 & - & $29.3( \pm 2.38)^{* * * *}$ & & $25.5( \pm 3.22) * * *$ \\
\hline & Harvest 2 & - & $10.9( \pm 2.38)^{* * *}$ & & $10.5( \pm 3.22)^{*}$ \\
\hline & Harvest 3 & - & $4.6( \pm 2.38)^{\mathrm{ns}}$ & & $-2.6( \pm 3.22)^{\mathrm{ns}}$ \\
\hline 2016 & Harvest 4 & - & $8.8( \pm 2.38)^{* *}$ & & $3.6( \pm 3.22)^{\mathrm{ns}}$ \\
\hline
\end{tabular}

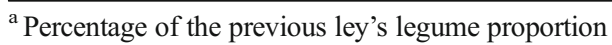

${ }^{\mathrm{b}} t$-test of difference in $\mathrm{N}$ yield between $\mathrm{Leg}_{50}$ and $\mathrm{Leg}_{\mathrm{mono}}$

${ }^{\mathrm{c}}$ Change in $\mathrm{N}$ yield of $L$. multiflorum grown at $\mathrm{Leg}_{50}$ and $\mathrm{Leg}_{\mathrm{mon}}$ as compared to L. multiflorum grown at Non-Leg $* * * P \leq 0.001, * * P \leq 0.01, * P \leq 0.05$, ns $P>0.05$

$\operatorname{Leg}_{\text {mono }}$ ) indicates that plant diversity imparts an influence, with several potential mechanisms responsible. It is known that the amount of symbiotically fixed $\mathrm{N}_{2}$ in grass-legume mixtures is also non-linear (Nyfeler et al. 2011) and that the legume species deposit much of their acquired $\mathrm{N}$ in the soil (Fustec et al. 2010; Hammelehle et al. 2018), allowing for transfer and uptake by the grass partner (Høgh-Jensen and Schjoerring 1997; Oberson et al. 2013). Additionally, mutual stimulation between grass and legume partners in mixtures enhance not only $\mathrm{N}$ uptake (Nyfeler et al. 2011), but also uptake of other soil resources such as phosphorus (Hoekstra et al. 2015; Husse et al. 2017). Together, these processes lead to greater biomass pools belowground which can then be subject to decay and mineralization. Moreover, 'non-N benefits' have been hypothesized and identified, such as carry-over rhizobacteria increasing macronutrient cycling and increasing plant tolerance to environmental stresses (Anderson 2011) and ameliorated soil structure (Karlen et al. 1994). Alterations in the soil matrix resulting from this collaborative interaction between the non-legume and legume components of the previous mixture sward may also have influenced the growth pattern of L. multiflorum. In reality, a complex interplay of varying interconnected processes may be responsible for the full magnitude of the legacy effect.

It has been shown that there is a significant increase in grass performance when it is grown in mixtures with legumes (Nyfeler et al. 2011). Our results advance our understanding of such mixtures, by demonstrating that such legume-mediated positive effects on grass performance can be sustained even when the legume component has been completely removed from the system. The legacy associated increase in the uptake of soil $\mathrm{N}$ by the following crop in this experiment provides an explanation for how legume-induced effects on biomass are sustained in mixed swards, even as the legume proportion declines, as was observed in the Agrodiversity Experiment (Brophy et al. 2017). The observation that mixtures with only $50 \%$ legume proportion produced comparable legume-legacy effects to legume monocultures has important agronomic implications, indicating that the optimal legacy benefits of legumes is achievable despite potential changes of legume proportion in mixtures. Lüscher et al. (2014) have suggested that legume proportions of $30-50 \%$ in mixed swards are most effective at positively affecting multiple functions in mixtures, including increased biomass yield, symbiotic $\mathrm{N}_{2}$ 
fixation, and nutritive value of forage. Given our results on legume-induced legacy effects and their saturation at around $50 \%$ legume proportion, a legume range as suggested by Lüscher et al. (2014) seems also suitable to result in substantial benefits for a following crop. Thus, this study highlights additional advantages to the proposed adoption of grass-legume mixtures for the development of competitive and sustainable ruminant production systems.

Acknowledgements We thank Hansueli Hirschi, Cornel Stutz, and Rafael Gago for technical assistance in the field and two anonymous reviewers for providing constructive comments on an earlier version of this paper. Funding was received from both the European Union's Seventh Framework Programme (FP7/ 2007-2013; grant agreement no. 266018) and through the 20152016 BiodivERsA COFUND call for research proposals with the national funder being the Swiss National Science Foundation (grant agreement no. 31BD30-172463).

Open Access This article is licensed under a Creative Commons Attribution 4.0 International License, which permits use, sharing, adaptation, distribution and reproduction in any medium or format, as long as you give appropriate credit to the original author(s) and the source, provide a link to the Creative Commons licence, and indicate if changes were made. The images or other third party material in this article are included in the article's Creative Commons licence, unless indicated otherwise in a credit line to the material. If material is not included in the article's Creative Commons licence and your intended use is not permitted by statutory regulation or exceeds the permitted use, you will need to obtain permission directly from the copyright holder. To view a copy of this licence, visit http://creativecommons.org/licenses/by/4.0/.

\section{References}

Anderson RL (2011) Synergism: a rotation effect of improved growth efficiency. In: Sparks DL (ed) Advances in agronomy, Vol 112. Elsevier Academic Press Inc, San Diego, pp 205-226

Borken W, Matzner E (2009) Reappraisal of drying and wetting effects on $\mathrm{C}$ and $\mathrm{N}$ mineralization and fluxes in soils. Glob Chang Biol 15:808-824. https://doi.org/10.1111/j.13652486.2008.01681.x

Brophy C, Finn JA, Lüscher A, Suter M, Kirwan L, Sebastià M-T, Helgadóttir Á, Baadshaug OH, Bélanger G, Black A, Collins RP, Čop J, Dalmannsdottir S, Delgado I, Elgersma A, Fothergill M, Frankow-Lindberg BE, Ghesquiere A, Golinska B, Golinski P, Grieu P, Gustavsson A-M, Höglind M, Huguenin-Elie O, Jørgensen M, Kadziuliene Z, Kurki P, Llurba R, Lunnan T, Porqueddu C, Thumm U, Connolly J (2017) Major shifts in species' relative abundance in grassland mixtures alongside positive effects of species diversity in yield: a continental-scale experiment. J Ecol 105:12101222. https://doi.org/10.1111/1365-2745.12754
Connolly J, Sebastià M-T, Kirwan L, Finn JA, Llurba R, Suter M, Collins RP, Porqueddu C, Helgadóttir Á, Baadshaug $\mathrm{OH}$, Bélanger G, Black A, Brophy C, Čop J, Dalmannsdóttir S, Delgado I, Elgersma A, Fothergill M, Frankow-Lindberg BE, Ghesquiere A, Golinski P, Grieu P, Gustavsson A-M, Höglind M, Huguenin-Elie O, Jørgensen M, Kadziuliene Z, Lunnan T, Nykanen-Kurki P, Ribas A, Taube F, Thumm U, De Vliegher A, Lüscher A (2018) Weed suppression greatly increased by plant diversity in intensively managed grasslands: a continental-scale experiment. J Appl Ecol 55:852862. https://doi.org/10.1111/1365-2664.12991

Crème A, Rumpel C, Le Roux X, Romian A, Lan T, Chabbi A (2018) Ley grassland under temperate climate had a legacy effect on soil organic matter quantity, biogeochemical signature and microbial activities. Soil Biol Biochem 122:203210. https://doi.org/10.1016/j.soilbio.2018.04.018

de Neergaard A, Hauggaard-Nielsen H, Stoumann Jensen L, Magid J (2002) Decomposition of white clover (Trifolium repens) and ryegrass (Lolium perenne) components: $\mathrm{C}$ and $\mathrm{N}$ dynamics simulated with the DAISY soil organic matter submodel. Eur J Agron 16:43-55. https://doi.org/10.1016 /S1161-0301(01)00118-6

Evans J, Fettell N, Coventry D, O'Connor G, Walsgott D, Mahoney J, Armstrong E (1991) Wheat response after temperate crop legumes in south-eastern Australia. Aust J Agric Res 42:31-43. https://doi.org/10.1071/AR9910031

Finn JA, Kirwan L, Connolly J, Sebastià MT, Helgadottir A, Baadshaug OH, Bélanger G, Black A, Brophy C, Collins RP, Čop J, Dalmannsdóttir S, Delgado I, Elgersma A, Fothergill M, Frankow-Lindberg BE, Ghesquiere A, Golinska B, Golinski P, Grieu P, Gustavsson A-M, Höglind M, Huguenin-Elie O, Jørgensen M, Kadziuliene Z, Kurki P, Llurba R, Lunnan T, Porqueddu C, Suter M, Thumm U, Lüscher A (2013) Ecosystem function enhanced by combining four functional types of plant species in intensively managed grassland mixtures: a 3-year continental-scale field experiment. J Appl Ecol 50:365-375. https://doi.org/10.1111 /1365-2664.12041

Franzluebbers AJ, Sawchik J, Taboada MA (2014) Agronomic and environmental impacts of pasture-crop rotations in temperate north and South America. Agric Ecosyst Environ 190: 18-26. https://doi.org/10.1016/j.agee.2013.09.017

Fustec J, Lesuffleur F, Mahieu S, Cliquet J-B (2010) Nitrogen rhizodeposition of legumes. A review. Agron Sustain Dev 30:57-66. https://doi.org/10.1051/agro/2009003

Hammelehle A, Oberson A, Lüscher A, Mäder P, Mayer J (2018) Above- and belowground nitrogen distribution of a red clover-perennial ryegrass sward along a soil nutrient availability gradient established by organic and conventional cropping systems. Plant Soil 425:507-525. https://doi. org/10.1007/s11104-018-3559-Z

Hansen JP, Vinther FP (2001) Spatial variability of symbiotic $\mathrm{N}_{2}$ fixation in grass-white clover pastures estimated by the ${ }^{15} \mathrm{~N}$ isotope dilution method and the natural ${ }^{15} \mathrm{~N}$ abundance method. Plant Soil 230:257-266. https://doi.org/10.1023 /a:1010390901845

Hoekstra NJ, Suter M, Finn JA, Husse S, Lüscher A (2015) Do belowground vertical niche differences between deep- and shallow-rooted species enhance resource uptake and drought resistance in grassland mixtures? Plant Soil 394:21-34. https://doi.org/10.1007/s11104-014-2352-x 
Hofer D, Suter M, Haughey E, Finn JA, Hoekstra NJ, Buchmann N, Lüscher A (2016) Yield of temperate forage grassland species is either largely resistant or resilient to experimental summer drought. J Appl Ecol 53:1023-1034. https://doi. org/10.1111/1365-2664.12694

Hofer D, Suter M, Buchmann N, Lüscher A (2017) Nitrogen status of functionally different forage species explains resistance to severe drought and post-drought overcompensation. Agric Ecosyst Environ 236:312-322. https://doi.org/10.1016/j. agee.2016.11.022

Høgh-Jensen H, Schjoerring JK (1997) Interactions between white clover and ryegrass under contrasting nitrogen availability: $\mathrm{N}_{2}$ fixation, $\mathrm{N}$ fertilizer recovery, $\mathrm{N}$ transfer and water use efficiency. Plant Soil 197:187-199. https://doi.org/10.1023 /a:1004289512040

Husse S, Lüscher A, Buchmann N, Hoekstra NJ, Huguenin-Elie O (2017) Effects of mixing forage species contrasting in vertical and temporal nutrient capture on nutrient yields and fertilizer recovery in productive grasslands. Plant Soil 420:505-521. https://doi.org/10.1007/s11104-017-3372-0

Johnson PO, Neyman J (1936) Tests of certain linear hypotheses and their application to some educational problems. Stat Res Mem 1:57-93

Karlen DL, Varvel GE, Bullock DG, Cruse RM (1994) Crop rotations for the $21^{\text {st }}$ century. In: Sparks DL (ed) Advances in Agronomy. Academic Press, Cambridge, Massachusetts, pp $1-45$

Ledgard SF, Steele KW (1992) Biological nitrogen fixation in mixed legume/grass pastures. Plant Soil 141:137-153. https://doi.org/10.1007/bf00011314

Ledgard S, Schils R, Eriksen J, Luo J (2009) Environmental impacts of grazed clover/grass pastures. Irish J Agr Food Res 48:209-226 https://www.jstor.org/stable/20720369

Lemaire G, Gastal F (1997) N uptake and distribution in plant canopies. In: Lemaire G (ed) Diagnosis of the nitrogen status in crops. Springer, Berlin, Heidelberg, pp 3-43

Lüscher A, Mueller-Harvey I, Soussana JF, Rees RM, Peyraud JL (2014) Potential of legume-based grassland-livestock systems in Europe: a review. Grass Forage Sci 69:206-228. https://doi.org/10.1111/gfs.12124

Murphy DV, Stockdale EA, Poulton PR, Willison TW, Goulding KWT (2007) Seasonal dynamics of carbon and nitrogen pools and fluxes under continuous arable and ley-arable rotations in a temperate environment. Eur J Soil Sci 58: $1410-1424$. https://doi.org/10.1111/j.13652389.2007.00946.x

Nakagawa S, Schielzeth H (2013) A general and simple method for obtaining $R^{2}$ from generalized linear mixed-effects models. Methods Ecol Evol 4:133-142. https://doi. org/10.1111/j.2041-210x.2012.00261.x

Nyfeler D, Huguenin-Elie O, Suter M, Frossard E, Lüscher A (2011) Grass-legume mixtures can yield more nitrogen than legume pure stands due to mutual stimulation of nitrogen uptake from symbiotic and non-symbiotic sources. Agric Ecosyst Environ 140:155-163. https://doi.org/10.1016/j. agee.2010.11.022

Oberson A, Frossard E, Bühlmann C, Mayer J, Mäder P, Lüscher A (2013) Nitrogen fixation and transfer in grass-clover leys under organic and conventional cropping systems. Plant Soil 371:237-255. https://doi.org/10.1007/s11104-013-1666-4
Peoples MB, Brockwell J, Herridge DF et al (2009) The contributions of nitrogen-fixing crop legumes to the productivity of agricultural systems. Symbiosis 48:1-17. https://doi. org/10.1007/BF03179980

Peoples MB, Swan AD, Goward L et al (2017) Soil mineral nitrogen benefits derived from legumes and comparisons of the apparent recovery of legume or fertiliser nitrogen by wheat. Soil Res 55:600-615. https://doi.org/10.1071 /SR16330

Pinheiro J, Bates D (2000) Mixed-effects models in S and S-plus. Springer, New York

Potthoff RF (2006) Johnson-Neyman technique. In: Kotz S, Read CB, Balakrishnan N, Vidakovic B, Johnson NL (eds) Encyclopedia of statistical sciences. Wiley, New York, pp 3745-3749

R Core Team (2019) A language and environment for statistical computing. R Foundation for Statistical Computing, Vienna http://www.R-project.org

Rasmussen J, Søegaard K, Pirhofer-Walzl K, Eriksen J (2012) $\mathrm{N}_{2}$ fixation and residual $\mathrm{N}$ effect of four legume species and four companion grass species. Eur J Agron 36:66-74. https://doi. org/10.1016/j.eja.2011.09.003

Shcherbak I, Millar N, Robertson GP (2014) Global metaanalysis of the nonlinear response of soil nitrous oxide $\left(\mathrm{N}_{2} \mathrm{O}\right)$ emissions to fertilizer nitrogen. Proc Natl Acad Sci U S A 111: 9199-9204. https://doi.org/10.1073/pnas.1322434111

Sieling K (2019) Improved N transfer by growing catch crops - a challenge. J Kult pflanzen 71:145-160. https://doi. org/10.5073/JfK.2019.06.01

Sievers T, Cook RL (2018) Aboveground and root decomposition of cereal rye and hairy vetch cover crops. Soil Sci Soc Am J 82:147-155. https://doi.org/10.2136/sssaj2017.05.0139

Soussana JF, Lemaire G (2014) Coupling carbon and nitrogen cycles for environmentally sustainable intensification of grasslands and crop-livestock systems. Agric Ecosyst Environ 190:9-17. https://doi.org/10.1016/j. agee.2013.10.012

Stevenson FC, van Kessel C (1996) The nitrogen and non-nitrogen rotation benefits of pea to succeeding crops. Can J Plant Sci 76:735-745. https://doi.org/10.4141/cjps96-126

Suter M, Connolly J, Finn JA, Loges R, Kirwan L, Sebastià M-T, Lüscher A (2015) Nitrogen yield advantage from grasslegume mixtures is robust over a wide range of legume proportions and environmental conditions. Glob Chang Biol 21:2424-2438. https://doi.org/10.1111/gcb.12880

Unkovich MJ, Pate JS, Sanford P, Armstrong EL (1994) Potential precision of the $\delta^{15} \mathrm{~N}$ natural abundance method in field estimates of nitrogen fixation by crop and pasture legumes in south-west Australia. Aust J Agric Res 45:119-132. https://doi.org/10.1071/AR9940119

Vose PB, Victoria RL (1986) Re-examination of the limitations of nitrogen-15 isotope dilution technique for the field measurement of dinitrogen fixation. In: Hauck RD, Weaver RW (eds) Field measurement of dinitrogen fixation and denitrification. Soil Science Society of America, Madison, pp 23-42

Publisher's note Springer Nature remains neutral with regard to jurisdictional claims in published maps and institutional affiliations. 